\title{
Land-Use/Land-Cover Change and Anthropogenic Causes Around Koupa Matapit Gallery Forest, West-Cameroon
}

\author{
Marie Caroline Momo Solefack ${ }^{1}$, André Ledoux Njouonkou², Lucie Félicité Temgoua ${ }^{3}$, Romuald Djouda \\ Zangmene ${ }^{1}$, Junior Baudoin Wouokoue Taffo ${ }^{1} \&$ Mama Ntoupka ${ }^{4}$ \\ ${ }^{1}$ Department of Plant Biology, Faculty of Science, University of Dschang, P.O. Box 67, Dschang, Cameroon \\ ${ }^{2}$ Department of Biological Sciences, Faculty of Science, University of Bamenda, P.O. Box 39, Bambili \\ ${ }^{3}$ Department of Forestry, Faculty of Agronomy and Agricultural Sciences, University of Dschang, Cameroon, P.O. \\ Box 222, Dschang, Cameroon \\ ${ }^{4}$ IRAD P.O. Box 170, Foumban, Cameroon \\ Correspondence: Marie Caroline Momo Solefack, Department of Plant Biology, Faculty of Science, University of \\ Dschang, P.O. Box 67, Dschang, Cameroon. E-mail: mcarofr@yahoo.fr / caroline.momo@univ-dschang.org
}

Received: April 8, 2018 Accepted: May 4, $2018 \quad$ Online Published: May 21, 2018

doi:10.5539/jgg.v10n2p56 URL: http://dx.doi.org/10.5539/jgg.v10n2p56

\begin{abstract}
This study assesses land cover change of the Koupa Matapit forest gallery, West Cameroon, in relation to anthropogenic factors. Ethnobotanical surveys were conducted to investigate the relationships between the local population and the gallery forest; the spatio-temporal dynamics of the landscapes around the gallery forest were studied from the diachronic analysis of three Landsat TM satellite images of 1984, Landsat ETM +1999 and Landsat OLI_TIRS of 2016, supplemented by verification missions on field. The satellite images were processed using ArcGIS and Erdas Imagine software. According to surveys, it should be noted that agriculture and livestock are the main economic activities of the population of Koupa Matapit, agriculture and fuel wood collection for energy were the main anthropogenic activities responsible for deforestation and degradation of the forest gallery. The collection of non-timber forest products (NTFPs) would have a significant implication in land use and cover changes. The results indicate that the extension of savannah/agricultural land (from 6989 ha in 1984 to 7604 ha in 2016) and bare soil/built up area (from 71 ha in 1984 to 342 ha in 2016) would have led to the disappearance of much of the forest area (1465 ha in 1984 to 580 ha in 2016). The rapid population growth of Koupa Matapit would be responsible for these pressures. There is an urgent need to implement appropriate land use policy in this area.
\end{abstract}

Keywords: Koupa Matapit, satellite images, landscape, NTFP, ethnobotany, land cover

\section{Introduction}

\subsection{Introduce the Problem}

The human population and human consumption of natural resources have increased steadily throughout the world since the origin of agriculture. The forest is a major source of food for the people of the Congo Basin. The contribution of forests to food security is often neglected, with human population living in and around forests deriving between one-fifth and one-quarter of their income from forest-based sources (Wollenberg et al., 2011). In addition to those living in the forest, many other peoples depend directly or indirectly on forest products for heating, food, medicines and other non-timber forest products (Megevand, 2013). Also, the increase of the population coupled with effects of climate change bring the farmers to look for new agricultural lands where water is available through the year like swamping areas or stream and riverborders. As a consequence, forests and other natural areas have been transformed into agriculture, pastureland, and cities. Land-use change, i.e. the transformation of natural land into agricultural and urban area, is among the most important human impacts on biodiversity and ecosystem functioning (Pereira et al., 2010). Land-use and land-cover change (LULCC) represents one of the most important components of global environmental change (Grau et al., 2003). Land-cover change is very intense in tropical developing countries that are characterized by agriculture-based economies and rapidly increasing human populations (Watson et al., 2001; Yeshaneh et al., 2013, Erika et al., 2015). In addition, land use remains an important factor in habitat degradation and destruction as well as biodiversity loss (Lucas et al., 2015). Remote sensing has proven to be an essential technology for determining land use and cover at different scales (Loveland 
and Dwyer, 2012; Hansen et al., 2013).

The gallery forests play an important role, that of a migration corridor that offers opportunities for genetic exchanges between geographically isolated populations (Ouédraogo, 2008). Today, under the combined effect of increase population and the need for cultivable land, gallery forests are being stormed by local populations and are subject to traditional land-use systems such as shifting cultivation, extensive livestock grazing, firewood collection and harvesting of non-timber forest products (Nacoulma et al., 2012). Cutting of gallery forests for agriculture may lead to an extension of savannah and open areas, especially near towns. Cattle can penetrate into the gallery forests in the savannah landscape and alter the structure of the forest. Further, cattle and agriculture can lead to soil erosion, which may alter the suitability for open areas to be recolonized.

In Cameroon, the law No. 94/01 of 20 January 1994 governing the forest, wildlife and fisheries regime seems to focus exclusively on logging without much concern for wildlife, local populations, indigenous peoples and vulnerable forest types such as mangroves, gallery forests and mountain forests. The small size of the gallery forests, their isolation and even their legal status are a threat to the biodiversity of these ecosystems. This paper, therefore, initiated a remote sensing-based vegetation baseline assessment that is nonexistent in Koupa Matapit forest gallery in western Cameroon, as a strategy for informing expert policy makers involved in the sustainable governance and development of the region. This is necessary to understand the dynamic nature of local vegetation and land cover types that may have been impacted over time. The information will be useful in streamlining policy efforts towards sustainable urban growth in the long-term, land cover recovery and agricultural resilience in the face of increasing changing climate. The following specific objectives have been addressed:

(1) to estimate the spatial extent of the vegetation cover changes using remotely sensed satellite data;

(2) to quantify the temporal changes $(1984,1999,2016)$ based on spatial extent of the vegetation cover;

(3) to identify and document responsible factors for the changes in terms of areal extent of the study area combined with farmers' perceptions.

\section{Method}

\subsection{Case Study Area}

Administratively, Koupa Matapit is situated in the West region of Cameroon, Noun Division and Foumban subdivision, at $13 \mathrm{~km}$ from the city of Foumban. Geographically, it is located between $5^{\circ} 43$ 'and $5^{\circ} 46^{\prime}$ north latitude and between $10^{\circ} 45$ and $10^{\circ} 54$ east longitude, $1180 \mathrm{~m}$ altitude (Atoupka, 2016). The soil is lateritic. The vegetation is dominated by shrub savannah with forest plantations of conifers (Cupressus, Pinus, etc.), and Eucalyptus saligna. This savannah is crossed by bands forest galleries along streams. The climate is of Cameroonian type, with a dry season from November to mit-March and a rainy season from mit-March to October. The temperature is relatively low (average $20^{\circ} \mathrm{C}$ ). The average annual precipitation is $1700 \mathrm{~mm}$. Two wind regimes dominate Koupa Matapit: the monsoon, wet southwest wind that causes the rains, and the opposite, the harmattan which is a northeasterly wind that causes drought. The relief is dominated by plains, plateaus and mountains or hills. Koupa Matapit is watered by several rivers such as Manoun, Ngouolam, Nchoutlue, Zonkpara. In 1967, the locality had 3,567 inhabitants (ORSTOM, 1968), composed mainly Bamoun tribe. As in many Cameroonian villages, the population of Koupa Matapit is growing rapidly. It has more than doubled in 38 years, since at the 2005 census (BUCREP, 2005), there were 8,327 inhabitants.

\subsection{Ethnobotanical Studies}

The ethnobotanical study was carried out following a series of surveys carried out using a pre-established questionnaire containing questions on: the respondant, the use of plants (particularly on non-timber forest products and wood), the parts used, the access to resources, the local perceptions of forest degradation, the relationship between the forest degradation and water availability, and the extinct or rare species.

Surveys mainly involved household heads and 30 people aged 35 to 85 were interviewed, including 8 women and 22 men. These surveys were carried out in 3 quaters of Koupa matapit: Kegou, Njikouet and Njilaré. The processing of ethnobotany survey data was based on the calculation of relative frequency of citation (RFC) using the Excel 2007 software. The RFC is the response rate by type of use. It is expressed by the formula used by Dossou et al. (2012).

$\mathrm{RFC}=\mathrm{S} / \mathrm{N} * 100$

With:

S: number of people who provided a response for a given use; 
$\mathrm{N}$ : total number of people interviewed.

\subsection{Estimation of Land Use and Land Cover Change}

\subsubsection{Remote Sensing and Field Data}

The remote sensing data consists of Landsat 5TM, Landsat 7ETM+ and Landsat 8OLI_TIRS satellite imagery, showing land use taken in 1984, 1999 and 2016, respectively. These images contain location information provided by the National Geospatial Agency (NGA) and the USGS (US Geological Survey) and are freely downloadable. Geocover images have the advantage of being orthorectified Landsat images, so they can be easily integrated into a geographic information system (GIS). They are supplied in standard Geotiff format with Universal Transverse Mercator (UTM) projection. The images were acquired approximately for the same period, at the beginning of the dry season to ensure that the phenological stages of plant cover were not too different between dates. Also, images captured in the dry season have the advantage of low cloud cover.

\subsubsection{Image Processing}

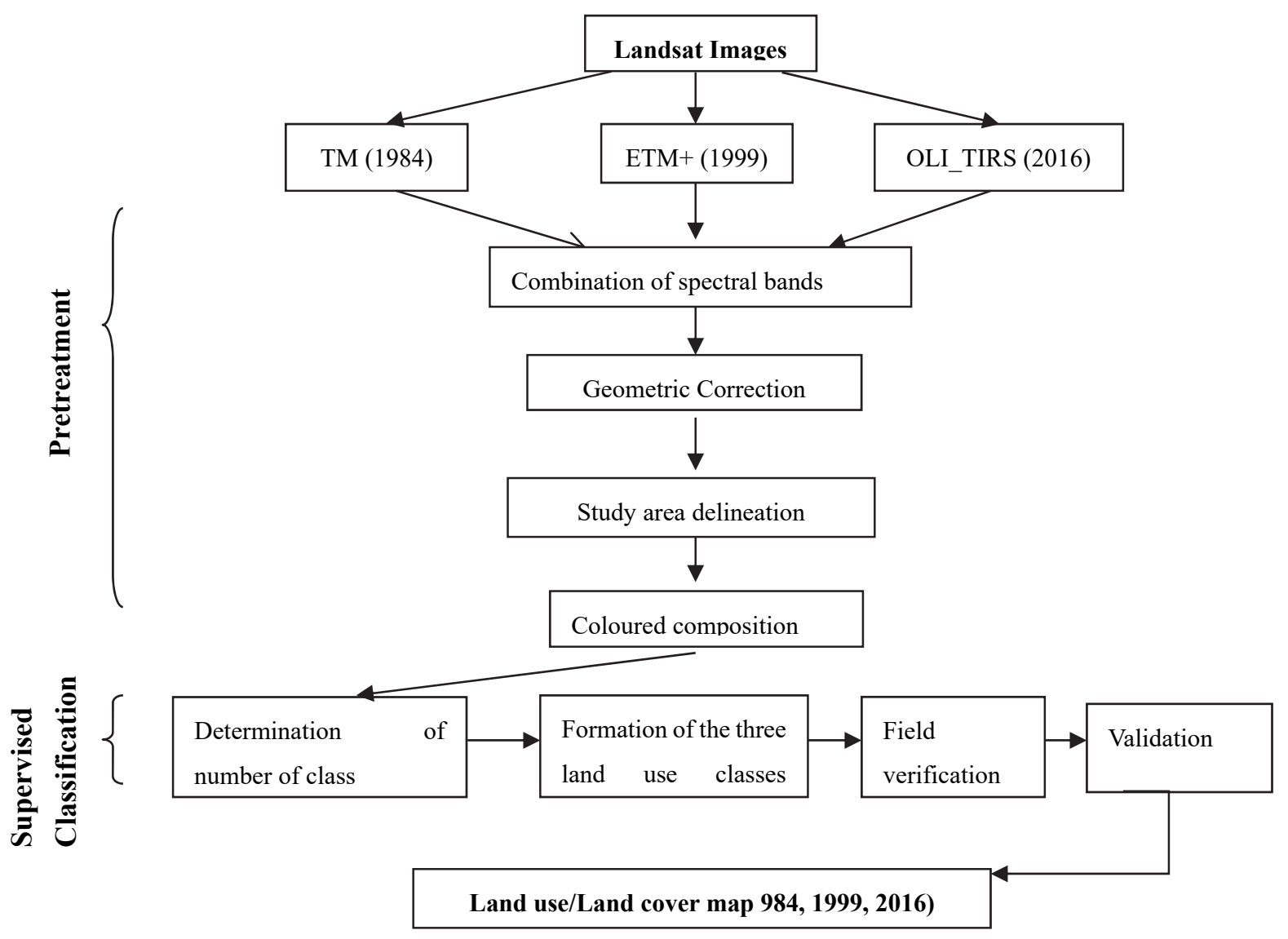

Figure 1. Flowchart showing the different stages of satellite images processing to obtain the land cover map

The first phase of the treatment consisted of the combination of the different spectral bands and permitted to obtain the images of the 3 dates. The images used were already all geo-rectified to UTM WGS 84 with radiometric corrections. To avoid geographical deviation between images due to differences in sensor when superimposing them for change detection analysis, the images of 1984 and 2000 were georectified to the image of 2016 already corrected using ground survey. Using ERDAS Imagine, the enhanced false colour composite bands of the different years depicting the vegetation image pixels were trained and categorized into appropriate classes. After adjusting the images, coloured compositions were created. Then, the study area was extracted from the scene to determine the land cover land use types by classifying images. We then carried out non-directed classifications that allowed us to segment the images into several sub-classes of land use. These subclasses were grouped into 3 main classes: 
Forest gallery, Savannah / croplands and bare soil / built-up area, from comparisons based on the different spectral signatures of Landsat images (Momo et al., 2012). The results from the classification were used to quantify the land cover and highlight the vegetation cover in 1984, 1999 and 2016. These treatments were carried out using ERDAS Imagine software. The images obtained were finally introduced into ArcGIS software for the realization of the map of land occupations of 3 dates.

\section{Results}

\subsection{Economic Activities and Use of Non-Timber Forest Products (NTFPs) by Local Populations}

The main economic activity is agriculture, which is practiced by $93 \%$ of respondents. In addition to agriculture, several secondary activities have been identified, among which those of healers $(30.7 \%)$, pastoralists $(23 \%)$, wood sellers (7\%), carpenter and merchant (14\%).

The survey revealed the need for NTFPs for the Koupa Matapit populations. Indeed, all respondents agreed that they use non-timber forest products from the forest, mainly for traditional medicine $(80 \%)$ and for food $(20 \%)$. The most used plant parts are leaves (38\%), followed by barks (27\%), roots (14\%), fruits (14\%), sap (6\%) and seeds $(1 \%)$.

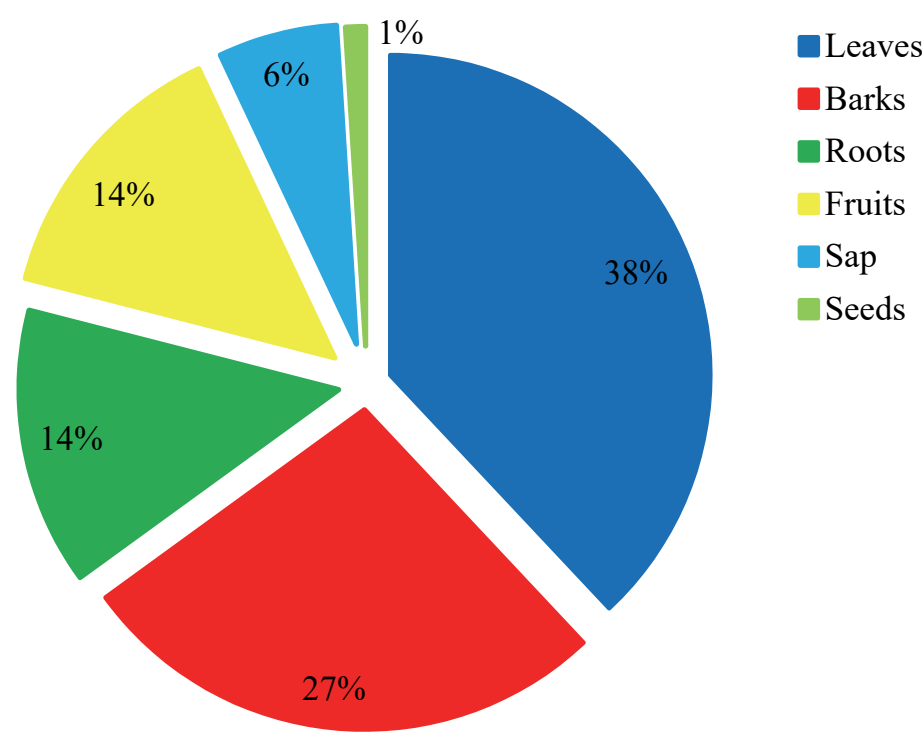

Figure 2. Proportion of plant parts used

The availability of NTFPs is sharply reduced as $48 \%$ of respondents find them less abundant and $24 \%$ say they are rarer to find today than in the past.

\subsection{Perceptions of Vegetation Degradation by Local Community}

The vegetation of Koupa Matapit appears to be progressively degraded. Indeed, $83 \%$ of the respondents answered in the affirmative to the question of whether the vegetation is degraded, against $17 \%$ who did not observe degradation. According to the locals, the main causes of the degradation of the native vegetation are agriculture, use of wood as a source of domestic energy, population increase and overgrazing. Many persons mentioned more than one of the above as causes; the figure 3 shows the frequency of citation of each of them. This degradation does not seem to have an influence on the availability of water resources since $80 \%$ of opinions were against this hypothesis. This degradation also resulted in the disappearance or rarefaction of certain plant species, the main ones being: Alchornea cordifolia Schmach. (Euphorbiaceae) locally known as "Mbouopvou", Polyscias fulva (Hiern) Harms (Araliaceae) named Pungue by locals and an unknown species call "Pepekwot by locals. 


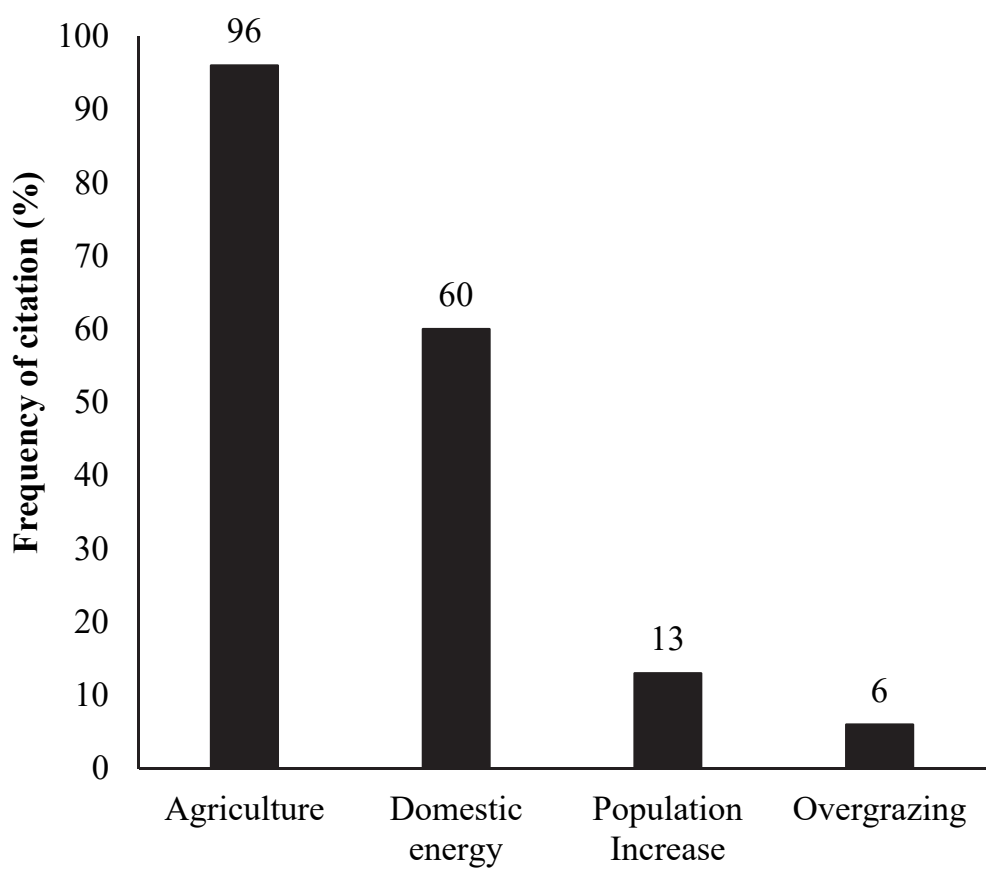

\section{Causes of vegetation degradation}

Figure 3. Frequency of citation of various causes of vegetation degradation by the local community

\subsection{Evolution of the Land Cover and Land Use}

The land use and land cover mapping identified three classes namely gallery forest, savanna/ croplands, and bare soil/built up area. Land cover statistics (Table 2) troughout the period of observation showed the dominance of savannah / croplands that is extending. The area covered by gallery forest decreased gradually from $17.19 \%$ in 1984 to $6.80 \%$ in 2016. Bare soil/built up area expanded slowly from $1984(0.83 \%)$ to $1999(1.46 \%)$ but became more than double between $1999(1.46 \%)$ and $2016(4.01 \%)$.

Table 1. Area (ha) and proportions (\%) of land cover types around the Koupa Matapit forest gallery in 1984, 1999 and 2016

\begin{tabular}{|c|c|c|c|c|c|c|}
\hline \multirow{2}{*}{$\begin{array}{l}\text { Land } \\
\text { use/Land } \\
\text { cover types }\end{array}$} & \multicolumn{2}{|c|}{1984} & \multicolumn{2}{|c|}{1999} & \multicolumn{2}{|c|}{2016} \\
\hline & Area (ha) & $\%$ & Area (ha) & $\%$ & Area (ha) & $\%$ \\
\hline $\begin{array}{l}\text { Gallery } \\
\text { Forest }\end{array}$ & 1465.40 & 17.19 & 1056.7 & 12.40 & 580.12 & 6.80 \\
\hline $\begin{array}{l}\text { Savannah / } \\
\text { Croplands }\end{array}$ & 6989.85 & 81.98 & 7344.82 & 86.14 & 7604.01 & 89.19 \\
\hline $\begin{array}{l}\text { Bare soil / } \\
\text { built up area }\end{array}$ & 71.28 & 0.83 & 125.01 & 1.46 & 342.4 & 4.01 \\
\hline Total Area & 8526.53 & & 8526.53 & & 8526.53 & \\
\hline
\end{tabular}

For the three different assessment occasions the gallery forest was dominated by savannah/croplands and bare soil/built-up area that together represented $82.81 \%$ of the area in $1984,87.6 \%$ in 1999 , and $93.2 \%$ in 2016 . The diachronic land cover maps obtained for the three periods are presented in Figure 4. 

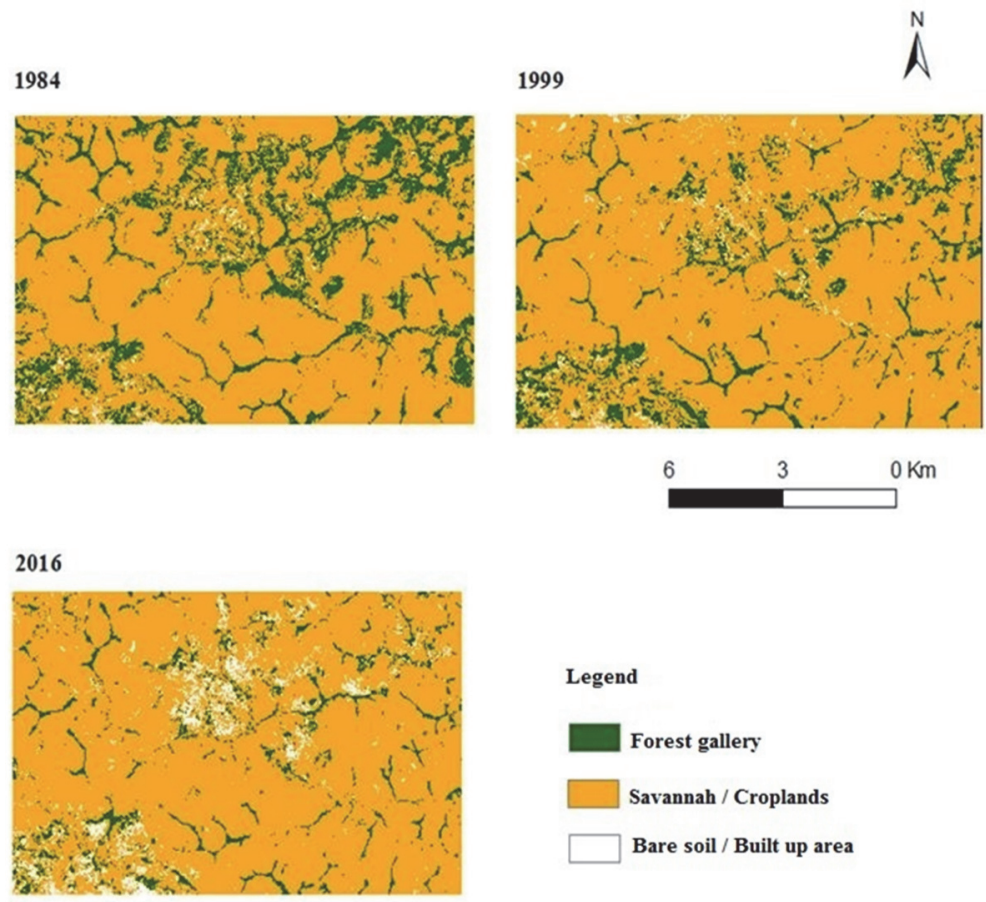

Figure 4. Maps of land occupations in 1984, 1999, 2016

As concerning land use land cover dynamics, the rate of change was positive in all periods for savannah/croplands and bare soil/built up area while that of forest gallery was negative (Figure 5). The overall annual rate of change (1984-2016) was highest for savannah/croplands with an increase of $7.21 \%$ and lowest for bare soil/built up area (3.18\%). Forest gallery recorded the greatest loss between 1984 and $2016(-10.39 \%)$.

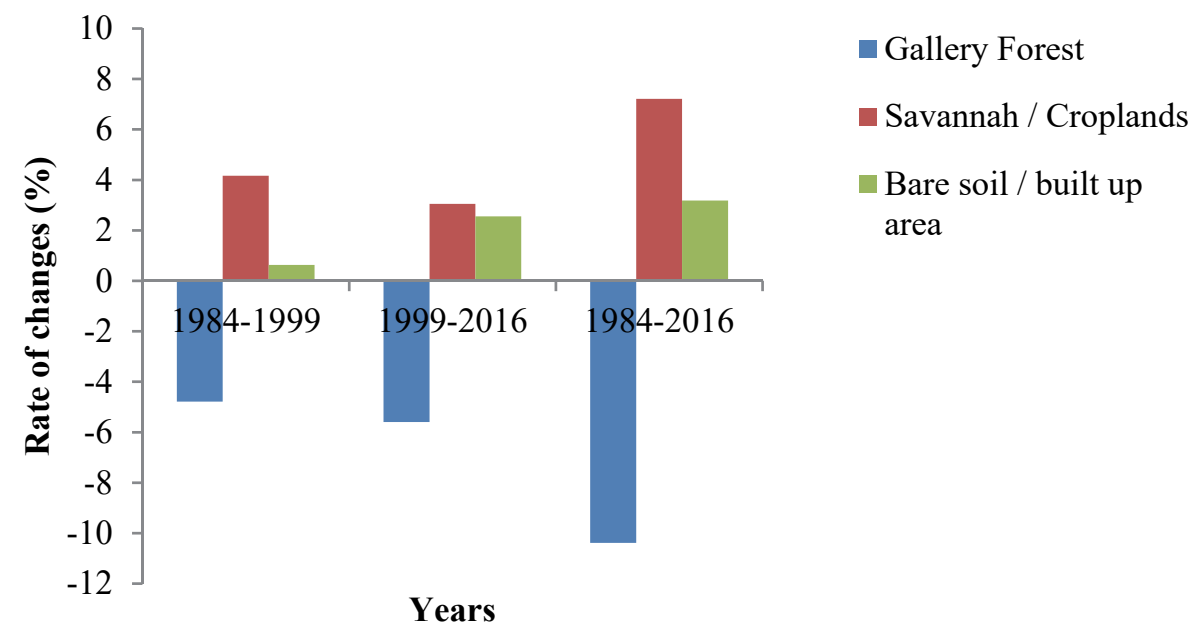

Figure 5. Annual rate of land cover change in Koupa Matapit gallery forest between 1984 and 2016

\section{Discussion}

\subsection{Impact of Socio-Economic Activities of the Koupa Matapit Population on Vegetation}

The main economic activities of the population of Koupa Matapit are agriculture and livestock. Atoupka (2016) made the same observation during his study on the diversity and uses of wood resources in the Koupa-Matapit area. These activities are largely responsible of the degradation of the gallery forest. Some farmers prefer to create farmland within the gallery forest because the gallery soil is richer than savannah soil and near the water soil. This observation is similar to that of Kondayen \& Kaine (2009) in the Ngoumbélé forest gallery in the Central African 
Republic. According to Dvorak \& Novak (1994), forest galleries have more fertile soils than neighboring ecosystems due to nutrients in the water stream associated with organic matter from litter decomposition. Thus, the search for new, fertile and wet farmland is causing the agricultural front to migrate to previously unexploited areas such as the banks of watercourses (Ouédraogo, 2008). Populations opt for a double annual crop by installing recessional crops on land with favorable conditions (Madjigoto, 2003). But these agrarian changes in response to pedoclimatic changes weaken natural ecosystems, including the gallery forests that naturally surround the rivers.

\subsection{Use of Non-Timber Forest Products (NTFPs)}

The surveys have shown that NTFPs are of great importance for local of Koupa Matapit who use them mainly for traditional medicine and for food. Harvesting NTFPs is a cause of forest degradation through loss of biodiversity (ITTO, 2002). Dan et al. (2012), in their study of the swamp forest of Lokoli in Benin pointed out that the almost daily human presence within the forest, the research and harvesting of NTFPs and other wood products are at the origin of the loss or the disappearance of species. In Koupa Matapit the populations reported that some species are becoming rare or extinct, among which are Alchornea cordifolia and Polyscias fulva. None of the both species is mention in the IUCN red list of threatened species; but are listed among useful plants and are mainly used in traditional medicine (Jeruto et al., 2008; Jiofack et al., 2010; Shalukoma et al., 2015). A. cordifolia is frequent in secondary forest and riverine forest; it is especially expended in marshy areas and sometimes in drier sites (Mavar-Manga et al., 2008). In savannah zone this species is generally found in forest galleries where the water content of the soil is high. Its rarety in Koupa Matapit is then intimately link with the diaspearence of gallery forests in favor of farmlands. Lescuyer (2010) made the same observations during his study of the economic importance of non-timber forest products in some villages in southern Cameroon, pointing out that farmers destroy some plants in order to make their path to the raffia plant. P. fulva is used in the West region of Cameroon especially the Noun division for the production of handicrafts. This has put a great pressure on it population in Foumban and vicinities so that crafters have go for a long distance before collecting it (Njoukam et al., 2008). This over exploitation is at the origine of the drastic reduction of this species in the study area that is very closed to Foumban. The increased exploitation of the various NTFPs leaves a significant impact on the ecosystem. In the Koupa Matapit forest gallery, the parts of the plants most used as NTFPs are leaves, bark and roots. Indeed, the use of bark and roots causes a vulnerability of plants (Betti, 2002). The same observations were made by Dan et al. (2012) in the swamp forest of Lokoli in southern Benin.

\subsection{Local Perception of Deforestation and Vegetation Degradation}

The majority of Koupa Matapit's population (83\%) thinks that the gallery forest is deteriorating and that the main causes are agriculture (96\%) and the use of wood as a source of energy $(60 \%)$. The main drivers of deforestation and degradation in the Congo Basin are the combination of several factors, including the expansion of peasant agriculture and timber extraction (Geist \& Lambin, 2002; Defourny et al., 2011). Anthropogenic factors are not the only ones that can influence this ecosystem. Environmental and climatic factors are probably also involved. Oliviera-Filho et al. (1994) have shown that changes in topography, edaphic factors, and flood intensity can affect riparian plant formations in streams. These degraded gallery forests then lose all of their multiple functions.

\subsection{Spatial and Temporal Evolution of Land use between 1984, 1999 and 2016}

Land cover change studies are crucial for the development of effective natural resource management plans (Gilani et al., 2015). The diachronic analysis of the Koupa Matapit forest landscape developed from the Landsat TM, ETM + and OLI_TIRS images on the region, allowed an effective monitoring of the landscape changes that occurred between 1984 and 2016. The good knowledge of the field led to the identification of the constitutive elements of the environment and a precise characterization of land use patterns in the realization of supervised classification. This approach has already been used in the analysis of land-use dynamics by many authors namely Frank (1984), Wafo et al. (2006).

The remote sensing data processing allowed us to observe that changes had occurred in land cover. In fact, we observed a decline of the forest gallery area, from 1465 ha in 1984 to 580 ha in 2016 . This decline is due to human activities, the main ones being agriculture and the new built. The presence of NTFPs species explains an intense resource withdrawal rate and a daily human presence within the plant communities concerned, conducting to the regression of the vegetation cover. These changes can be attributed to a number of factors including rapid population growth and land scarcity which have forced farming households to expand their agricultural fields into natural environments in order to be to increase their agricultural productions and cover their daily household's needs. Rapid population growth in Koupa Matapit, from 3.567 inhabitants in 1967 (ORSTOM, 1968) to 8.327 inhabitants in 2005 (BUCREP, 2005) has also resulted to clearance of natural vegetation to allow room for settlement. As a result, large areas, which were under natural vegetation cover, are now exposed to clearance, 
which has resulted to environmental degradation and threat to biodiversity and wild life habitat loss.

Deforestation in the Congo Basin is correlated with population density and related subsistence activities (agriculture and energy) that usually occur at the expense of the forest (Dibi et al., 2008). This study provides a basis for planning and planned conservation and development interventions. The results will not only help fill the data gap for Koupa Matapit and the West Cameroon region, but they will also contribute to a better understanding of global change and the underlying causes, as global data on coverage change poor (Turner et al., 1994), and the need for a local assessment of land cover, particularly in developing countries, has been highlighted by several studies (Lambin et al., 2003; Vadrevu et al., 2015). Similar studies in the Laf-Madjam Forest Reserve in Cameroon (Wafo et al., 2006) have shown that population growth and resource pressures result in a decline in vegetation cover and uncontrolled exploitation of arable land, reflecting the difficulties, in a weakly intensified system, of feeding a population which is increasing at a rate of $2 \%$ per year (Bergonzini \& Lanly, 2000). These results are not only observable in Cameroon because, in the tropics, the development of human activities such as agriculture has an immediate impact on land use and a direct impact on forest cover (Mather \& Needle, 2000; Geist \& Lambin, 2002; Jansen et al., 2008).

\section{Conclusion}

In Koupa Matapit, the forest gallery cover is reduicing despite its contribution to the daily life of the locals due to the growing needs of its rapidly expanding population. The main activities at the base of this is agriculture that here is for subsistence and rudimentary. Construction of new human habitat can also be taking in to consideration as driver to this alteration. The lack of conservation of this forest and other natural ecosystems can be attributed to to the weak land use and planning policy It is therefore capital to put in place a local policy of conservation and sustainable management of this particular ecosystem according to the national forest law and this should be extended to other villages. Also, the present data obtained can be used by a wider range stackholder for the planification of the sustainable land use and management in Koupa Matapit. After a general overview of land cover and related causes, it would be necessary to conduct a phytosociological study to understand the impact of human activities on phytodiversity at a smaller scale.

\section{References}

Ariti, A. T., van Vliet, J., \& Verburg, P. H. (2015). Land-use and land-cover changes in the Central Rift Valley of Ethiopia: Assessment of perception and adaptation of stakeholders. Applied Geography, 65, 28-37. http://dx.doi.org/10.1016/j.apgeog.2015.10.002

Atoupka, A. M. (2016). Diversités et usages des ressources ligneuses dans le terroir de Koupa Matapit, Ouest Cameroun. Mémoire d'Ingénieur des Eaux, Forêts et Chasses, FASA, Cameroun, 143p

Bergonzini, J. C., \& Lanly, J. P. (2000). Les forêts tropicales, Cirad, Karthala, 164p

BUCREP (2005). Troisième recensement général de la population et de l'habitat (3e RGPH, 2005), Bureau central des recensements et des études de population du Cameroun.

Dan, C. B. S., Sinsin, B. A., Mensah, G. A., \& Lejoly, J. (2012). Influence des activités anthropiques sur la diversité floristique des communautés végétales de la forêt marécageuse de Lokoli au Sud-Bénin. Int. J. Biol. Chem. Sci., 6(6), 3064-3081. http://dx.doi.org/10.4314/ijbcs.v6i6.8

Defourny, P., Delhage, C., \& Kibambe Lubamba, J. P. (2011). Analyse quantitative des causes de la déforestation et de la dégradation des forêts en République Démocratique du Congo. UCL/FAO/CN REDD, Kinshasa.

Dibi, N'Da H., N'Guessan, K. E., Wadja, M. E., \& Affian K. (2008). Apport de la télédétection au suivi de la déforestation dans le parc national de la Marahoué (côte d'ivoire). Revue Télédétection, 8 (1), 17-34.

Dossou, M. E., Houessou, G. L., Lougbégnon, O. T., Tenté, A. H. B., \& Codjia, J. T. C. (2012). Étude ethnobotanique des ressources forestières ligneuses de la forêt marécageuse d'Agonvè et terroirs connexes au Bénin. Tropicultura, 3 (1), 41-48.

Dubula, B., Tesfamichael, S. G., \& Rampedi, I. T. (2016). Assessing the potential of remote sensing to discriminate invasive Asparagus laricinus from adjacent land cover types. Cogent Geoscience, 2(1), 1-17.

Dvorak J., \& Novak L. (1994). Soil Conservation and Silviculture, Develop. Soil Science, 23, Elsevier, Prague

Erika, R., Celso, B. L., Martin, H., Erik, L., Robert, O., Arief, W., Daniel, M., \& Louis, V. (2015). Assessing change in national forest monitoring capacities of 99 tropical Countries. Forest Ecology and Management, 352, 109123.

Forkel, M., Carvalhais N., Verbesselt J., Mahecha M. D., Neigh S. R. C., \& Reichstein M. (2013). Trend change 
detection in NDVI time series: Effects of inter-annual variability and methodology. Remote Sensing, 5, 2113 2144. https://doi.org/10.3390/rs5052113

Frank, T. D. (1984). Assessing change in the surfacial character of a semi-arid environment with Landsat residual images. Photogrammetric Engineering and Remote Sensing, L(4), 471-480.

Geist, H. J., \& Lambin, E. F. (2002). Proximate causes and underlying driving forces of tropical deforestation. BioScience, 52(2), 143-150.

Gilani, H., Shrestha, H. L., Murthy, M. S. R., Phuntso, P., Pradhan, S., Bajracharya, B., \& Shrestha, B. (2015). Decadal land cover change dynamics in Bhutan. Journal of Environmental Management, 148, 91-100. https://doi.org/10.1016/j.jenvman.2014.02.014

Grau, H. R., Aide, T. M., Zimmerman, J. K., Thomlinson, J. R., Helmer, E., \& Zou, X. (2003). The Ecological Consequences of Socioeconomic and Land-Use Changes in Postagriculture Puerto Rico. BioScience, 53(12), 1159-1168.

Hansen, M. C., Potapov, P. V., Moore, R., Hancher, M., Turubanova, S. A., Tyukavina, A., ... Townshend, J. R. G. (2013). High-resolution global maps of 21st-century forest cover change. Science, 342, 850-853.

Hansen, M. C., Stehman, S. V., \& Potapov, P. V. (2010). Quantification of global gross forest cover loss. Proceedings of the National Academy of Sciences of the United States of America, 107(19), 8650-8655.

Jansen, L. J. M., Carrai, G., Morandini, L., Cerutti, P. O., \& Spisni, A. (2008). Analysis of the spatio-temporal and semantic aspects of land-cover/use change dynamics 1991-2001 in Albania at national and district levels. Environ. Monit. Assess., 119, 107-136.

Jeruto, P., Lukhoba, C., Ouma, G., Otieno, D., \& Mutai, C. (2008). An ethnobotanical study of medicinal plants used by the Nandi people in Kenya. Journal of Ethnopharmacology, 116, 370-376. doi: 10.1016/j.jep.2007.11.041

Jiofack, T., Guedje, N., Ayissi, I., Fokunang, C., Usongo, L., \& Nkongmeneck, B. A. (2010). Upper Nyong valley forest in Cameroon: Ethnobotanical uses and implications for biodiversity conservation. International Journal of Biodiversity and Conservation, 2(11), 370-381.

Kondayen, I. A., \& Kaine, E. V. (2009). Cogestion de la galerie forestière de Ngoumbélé, République centrafricaine, pour un meilleur contrôle des ressources par les populations riveraines. L. Seiny-Boukar, P. Boumard. Savanes africaines en développement : innover pour durer, Garoua, Cameroun. Cirad, 10 p.

Lambin, E. F., Geist, H. J., \& Lepers, E. (2003) Dynamics of Land-Use and Land-Cover Change Tropical Regions. Annual Review of Environment and Resources, 28, 205-241. http://dx.doi.org/10.1146/annurev.energy.28.050302.105459

Lescuyer, G. (2010). Importance économique des produits forestiers non ligneux dans quelques villages du SudCameroun. Bois et Forêts des Tropiques, 304(2), 15-24.

Loveland, T. R., \& Dwyer, J. L. (2012). Landsat: Building a strong future. Remote Sensing of Environment, 122, 22-29. http://dx.doi.org/10.1016/j.rse.2011.09.022

Lucas, R., Blonda, P., Bunting, P., Jones, G., Inglada, J., Arias, M., ... Mairota, P. (2015). The earth observation data for habitat monitoring (EODHaM) system. International Journal of Applied Earth Observation and Geoinformation, 37, 17-28. http://dx.doi.org/10.1016/j.jag.2014.10.011

Madjigoto, R. (2003). Des cultures pluviales à la culture de décrue : une adaptation du système de culture aux changements climatiques. L'exemple du terroir de Moudourou, Tchad. Organisation spatiale et gestion des ressources et des territoires ruraux, Actes du colloque international, 25-27 Février 2003, Montpellier, France, Umr Sagert, Cnearc.

Mather, A. S., \& Needle, C. L. (2000). The relationships of population and forest trends. Geographical Journal, $166,2-13$.

Megevand, C. (2013). Dynamiques de déforestation dans le bassin du Congo: Réconcilier la croissance économique et la protection de la forêt. Washington, DC: World Bank. http://dx.doi.org/10.1596/978-0821숙-9827-2

Mavar-Manga, H., Lejoly, J., Quetin-Leclercq, J. \& Schmelzer, G. H., (2007). Alchornea cordifolia (Schumach. \& Thonn.) Müll.Arg. [Internet] Record from Protabase. Schmelzer, G.H. \& Gurib-Fakim, A. (Editors). PROTA (Plant Resources of Tropical Africa / Ressources végétales de l'Afrique tropicale), Wageningen, 
Netherlands. $<$ http://database.prota.org/search.htm>. Accessed 18 April 2008.

Momo Solefack, M. C., Chabrerie, O., Gallet-Moron, E., Nkongmeneck, B. A., Leumbe Leumbe, O. N., \& Decocq, G. (2012). Analyse de la dynamique de déforestation par télédétection couplée aux modèles d'équations structurales: exemple de la forêt néphéliphile du mont Oku (Cameroun). Acta Botanica Gallica, 159(4), 451466. http://dx.doi.org/10.1080/12538078.2012.750583

Nacoulma, B. M. I., Schumann, K., Traoré, S., Bernhardt-Römermann, M., Hahn, K., Wittig, R., \& Thiombiano, A. (2012). Impacts of land-use on West African savanna vegetation: a comparison between protected and communal area in Burkina Faso. Biodiversity and Conservation, 20, 3341-3362.

Njoukam, R., Neba, D. A., Peltier R., \& Temgoua, L. F. (2008). Artisanat et Sylviculture Paysanne dans l'OuestCameroun. Le Flamboyant, 64, 19-23.

OIBT (2002). Directives OIBT pour la restauration, l'aménagement et la réhabilitation des forêts tropicales dégradées et secondaires. Série OIBT : Politique forestière $n^{\circ} 13$, Yokohama. $92 \mathrm{p}$

Oliveira, F. A. T., Almeida, R. J., Mello, J. M., \& Gavilanes, M. L. (1994). La structure phytosociologique et les variables environnementales sur un tronçon de flux riverain de Vilas Boas, Réserve biologique bonite Eh bien, Lavras (MG). Revista Brasileira de Botânica, 17, 67-85.

ORSTOM (1968). Dictionnaire des villages du département Bamoun. Répertoire géographique du Cameroun, 16 : $38 \mathrm{p}$.

Ouédraogo, M. (2008). Les galeries forestières de la Réserve de la Biosphère de la Mare aux Hippopotames du Burkina Faso : caractéristiques, dynamique et ethnobotanique. Doctorat d'Etat ès Sciences Naturelles. Université Ouagadougou. $279 \mathrm{p}$

Pereira, H. M., Leadley, P. W., Proenca, V., Alkemade, R., Scharlemann, J. P., Fernandez-Manjarres, J. F., ... Walpole, M. (2010). Scenarios for global biodiversity in the 21st century. Science, 330(6010), 1496-1501, https://doi.org/10.1126/science.1196624

Shalukoma, C., Bogaert, J., Duez, P., Stévigny, C., Pongombo, C. \& Visser, M. (2015). Les plantes médicinales de la région montagneuse de Kahuzi-Biega en République Démocratique du Congo: utilisation, accessibilité et consensus des tradipraticiens. Bois Et Forêts Des Tropiques, 326 (4), 43 - 55.

Turner, II, B. L., Meyer, W. B., \& Skole, D. L. (1994). Global land-use/land-cover change: towards an integrated program of study. Ambio, 23, 91-95.

Vadrevu, K.P., Justice, C., Prasad, T., Prasad, N., \& Gutman, G. (2015). Land cover/land use change and impacts on environment in South Asia. J Environ Manage., 148, 1-3. https://doi.org/10.1016/j.jenvman.2014.12.005

Wafo, T. G., Tsayem Demaze, M., \& Fotsing, J. M. (2006). L'information spatialisée comme support d'aide à la gestion des aires protégées au Cameroun: application à la réserve forestière de Laf-Madjam. Interactions Nature-Société, analyse et modèles. UNR6554 LETG, La Baule.9p.

Watson, R. T., Noble, I. R., Bolin, B., Ravindranath, N. H., Verardo, D. J., \& Dokken, D. J. (2001). Land Use, Land Use Change, and Forestry. Cambridge (United Kingdom): Cambridge University Press.

Wollenberg, E., Campbell, B. M., Holmgren, P., Seymour, F., Sibanda, L., \& Braun, J. (2011). Actions needed to halt deforestation and promote climate-smart agriculture. CCAFS Policy Brief 4. Climate Change Agriculture and Food Security CCAFS. Copenhague, Danemark.

Yeshaneh, E., Wagner, W., Exner-Kittridge, M., Legesse, D., \& Blöschl, G. (2013). Identifying land use/cover dynamics in the Koga catchment, Ethiopia, from multi-scale data, and implications for environmental change. ISPRS International Journal of Geo-Information, 2, 302-323. http://dx.doi.org/10.3390/ijgi2020302

\section{Copyrights}

Copyright for this article is retained by the author(s), with first publication rights granted to the journal.

This is an open-access article distributed under the terms and conditions of the Creative Commons Attribution license (http://creativecommons.org/licenses/by/4.0/). 